\title{
Article \\ Role and Significance of the United Arab Emirates Foreign Aid for Its Soft Power Strategy and Sustainable Development Goals
}

\author{
Adam Krzymowski
}

check for updates

Citation: Krzymowski, Adam. 2022 Role and Significance of the United Arab Emirates Foreign Aid for Its Soft Power Strategy and Sustainable Development Goals. Social Sciences 11: 48. https://doi.org/10.3390/ socsci11020048

Academic Editor: Andreas Pickel

Received: 2 December 2021

Accepted: 7 January 2022

Published: 28 January 2022

Publisher's Note: MDPI stays neutral with regard to jurisdictional claims in published maps and institutional affiliations.

Copyright: (C) 2022 by the author. Licensee MDPI, Basel, Switzerland. This article is an open access article distributed under the terms and conditions of the Creative Commons Attribution (CC BY) license (https:// creativecommons.org/licenses/by/ $4.0 /)$
International Affairs Department, Zayed University, Abu Dhabi P.O. Box 144534, United Arab Emirates; ak7@vp.pl

\begin{abstract}
The main issue in the presented research is the United Arab Emirates' foreign aid commitment, the development of its brand, and its position in international relations. The study's purpose is to find an answer to a research question, specifically, what is the UAE foreign aid role and significance for the Soft Power Strategy implementation and the Sustainable Development Goals? The author adopted appropriate theories and research methods. Role theory has been applied, allowing for the combination of different tools. Moreover, there is a close connection between the state adapting to changes in its political environment and its position and role in international relations. Therefore, the theory of adaptation has also been included. To verify the theoretical assumptions, the author implemented a comparative analysis using empirical research and case studies. In addition, the author's ten-year participation in many UAE international policy processes was useful. The paper shows United Arab Emirates foreign aid as a fundamental element of supporting branding, filling the Sustainable Development Goals, and influencing international relations. In the twenty-first century, UAE foreign aid became a pillar of state foreign policy, making it possible to shape the international environment.
\end{abstract}

Keywords: United Arab Emirates; foreign aid; soft power strategy; sustainable development goals

\section{Introduction}

Since its inception in 1971 until the end of 2019, the United Arab Emirates transferred over USD 80 billion in foreign aid. In 2019, UAE foreign aid exceeded USD 8 billion. Since 2013, the United Arab Emirates has been the top global foreign aid donor. Therefore, this publication aims to answer the following research question: what is the role and importance of the UAE's foreign aid for the implementation of the Soft Power Strategy and the Sustainable Development Goals (SDGs)? The research results show that foreign aid is the adaptation result to changes to the new international environment. This refers to the changes in global affairs that took place in 2001 and then again in 2011, after the start of the so-called Arab Spring, which had a fundamental influence on international relations on the political, economic, and military levels. This research significantly influenced the foreign aid policy of the UAE. The complex situation in the Middle East at the beginning of the 21st century became apparent, more so as the Western world was also looking for its place and role in post-Cold War conditions at that time. The United Arab Emirates, aiming to strengthen its position in the Middle East and North Africa, implemented many initiatives. To realize this concept, the UAE adopted certain types of international roles. First, the adopted the role of the donor who invests resources to promote the economic development and prosperity of friendly partners. Secondly, the UAE adopted the promoter role, actively seeking opportunities to recruit new partners. Therefore, it can be concluded that the implementation of the UAE foreign aid policy has contributed to strengthening the country's political influence in international relations. This had allowed the United Arab Emirates to pursue its interests more effectively as well as on a global scale. The dynamic development of foreign aid has become a pillar of the Soft Power Strategy adopted in 2017. 
In addition, foreign aid has been linked to the SDGs, strengthening the country's brand internationally. The role of the foreign aid donor that has been declared and implemented by the United Arab Emirates has determined its position in international relations.

The research question will be answered, and the results will be valuable for both international relations researchers and practitioners. Moreover, the case study findings on relations between the United Arab Emirates and the European Union indicate the potential and political will to deepen cooperation between these partners in the field of foreign aid.

\section{Materials and Methods}

For several years, there has been more and more research and analysis on the foreign aid delivered by the United Arab Emirates. The reason for this is that for 10 years, the Ministry of Foreign Affairs and International Cooperation have published reports on this subject regularly. In addition, the UAE is consistently at the forefront of the world as a foreign aid donor. However, so far, not enough foreign aid has been given. Moreover, there has been no study focussing on foreign aid from the United Arab Emirates from the soft power perspective, which considers the dynamics of cooperation with the European Union. Therefore, the presented work is an innovative study and contribution to the development of research. At the same time, it used the author's previously conducted research. The publication "The European Union and the United Arab Emirates as civilian and soft powers engaged in Sustainable Development Goals" (Krzymowski 2020c), presents the research results on deepening the relationship between world leaders in providing humanitarian aid. However, in the manuscript "Expo2020 Dubai on the journey to achieve the United Arab Emirates' Soft Superpower" (Krzymowski 2020a), the researcher analysed UAE instruments and activity as soft power. The article entitled "Sustainable Development Goals in Arab Region-United Arab Emirates' Case Study" (Krzymowski 2020b) presents research results on the SDGs. However, these publications do not focus on the role and importance of foreign aid. Therefore, this article supplements the research that has been conducted so far by including this significant element. When analysing the scientific research conducted by other authors so far, it is necessary to point out the article by Almatrooshi (2019), who investigated the impact of the UAE's foreign policy on the fulfilment of the Sustainable Development Goals. Lootah's (2019) research also went in this direction. Cochrane (2021) presented the motivations for becoming involved in humanitarian aid. Forrey (2020) showed the historical development of the UAE in terms of foreign aid. In his research, Gökalp (2020) emphasized humanitarian diplomacy. On the other hand, Saberi et al. (2018) analysed UAE soft power in their study. However, they focused on the importance of tourism. Woodward's research work showed this issue from a broader point of view.

The theory of adaptation and role helps to find an answer to the research question posed in this paper. In the context of foreign policy, the foreign aid that is part of it is related. The state assumes a specific role in international relations as an adaptation to the changes taking place in those states (Rosenau 1981). At the same time, three different adaptive attitudes should be indicated, i.e., passive, submissive, and creative. The UAE's foreign aid policy is evidence of creative adaptation. International relations researchers should also raise issues of creativity (Kodabux 2019). Recently, global players have been implementing more and more global strategies that are based on creative activities, which show new ways of achieving goals. However, proactivity is a prerequisite for effectiveness (Baba and Kaya 2014). Consequently, creativity strengthens soft power by generating new methods of influencing other participants in international relations (Evans and Bruce 1991, p. 325). Moreover, small countries can naturally be much more flexible. Thus, they can be much more creative in foreign policy (Katzenstein 1985).

Creative adaptation is a model based on activity aimed at shaping the changing international situation following national interest. Conway and Feigert (1987, pp. 136-39) point out that this process demonstrates its role and position concerning other participants. In this way, an interaction process takes place, hence the interaction and influence. In turn, it shapes the place and roles in their relationships (Keohane 2012, p. 19). This is especially 
the case in the donor-beneficiary relationship. Therefore, foreign aid is of fundamental importance in the foreign policy of the United Arab Emirates. Thus, the role theory made it possible to conduct an accurate investigation of the UAE's foreign policy and its instruments, including foreign aid (Walker 1987, p. 244). However, to verify the hypothesis based on the theories of role and adaptation, the author adopted appropriate research methods. In addition to the adopted theories of international relations, this study relies on descriptive and analytical methods. To find an answer to the research question, the author used empirical and analytical studies. The main category of comparisons is the dynamics of foreign aid provided in 2013-2019, projects, and the political context. The research also examined the state and non-state actors in the UAE who are involved in the Soft Power Strategy and in Sustainable Development Goals implementation. The relationship between the UAE and the European Union was selected as a case study. Developing international alliances is a crucial element of soft power. Therefore, the rationale for this choice is that the European Union, as an international organization comprising its member states, has been successful in achieving the SDGs. Moreover, the UAE has intensified cooperation with the European Union in recent years. In implementing the research assumptions, the author applied qualitative methods. This has contributed to determining a deeper cause, analysis, effects, and dependencies of the studied processes. In turn, it has helped in finding an answer to the research question. Critical analysis of the research material based on the adopted theories and applied methods produced the research results. In addition, the research material was investigated using the author's practice and direct observations of the studied area. Thus, the adopted theoretical and methodological apparatus was verified from the point of view of practice.

\section{Results}

\subsection{UAE Foreign Policy and Humanitarian Diplomacy}

\subsubsection{Institutionalization of Foreign Policy and Aid}

The first president of the United Arab Emirates, H.H. Sheikh Zayed bin Sultan Al Nahyan, underlay that foreign aid must be a crucial part of the state's foreign policy. Therefore, the foundations of the United Arab Emirates foreign aid policy were laid by its founder. In 1971, the year in which the UAE was founded, the foreign aid agency Abu Dhabi Fund for Development (ADFD) had already been established. On 31 January 1983, the UAE Red Crescent Authority was opened. It has become one of the most important institutions involved in humanitarian aid. Thus, from the beginning of the United Arab Emirates' existence, foreign aid has been one of the pillars of the country's foreign policy (Al Zaabi and Awamleh 2019, pp. 67-79). In 1986, the organization became a member of the International Federation of Red Crescent and Red Cross. In 1989, Sharjah Charity International was founded. The organization aims to provide humanitarian aid to people in the country and abroad. It assists nations during natural disasters and wars. The wife of president and founder of statehood, Her Majesty Sheikha Fatima bint Mubarak, "Mother of the Nation" became honorary chairwoman in 1997. At that time, she was already very famous for her social and charitable activities. She founded the Abu Dhabi Women's Development Association in 1973 and the General Women's Union (GWU) in 1975. In 1994, Her Majesty was elected Chairwoman of the Coordination Committee for Women's Action in the Gulf and Arabian Peninsula. In 1997, Mohammad Bin Rashid Al Maktoum Charity and Humanitarian and Charity Establishment (MBRCH) was also founded. The main goal of this organization is to help the poor, widows, orphans, as well as the needy and suffering all over the world. In addition, it participates in providing humanitarian aid in areas that have been affected by disasters and wars. Facing the new security challenges of the Western Balkans in the 1990s, the UAE provided significant foreign aid to the region at the turn of the century. Thus, by granting financial assistance to Kosovo in 1999, the UAE contributed to conflict resolution. Another example is the loans and grants provided to Albania by the Abu Dhabi Development Fund (ADFD). In addition, the United Arab 
Emirates has become Macedonia's largest non-EU donor, and in Serbia, it has become the largest investor (Bartlett et al. 2017).

From the very beginning of UAE statehood, humanitarian aid has become a significant element of foreign policy, serving to adapt to new challenges. Since then, the United Arab Emirates has assumed the donor role outside of the Middle East.

\subsubsection{Humanitarian Diplomacy of the 21st Century}

In 2001, the United Arab Emirates Red Crescent was elected the second-best humanitarian organization in Asia. Humanitarian goals quickly brought benefits to the state image and strengthened the country's international position. Thus, naturally, foreign aid has become a crucial element of UAE soft power and an instrument for the effective implementation of political and economic goals. The beginning of the 21st century has been a period of dynamic changes in the global security structure, with consequences for the Middle East and North Africa regions. In 2003, the year in which the US began its military intervention of Iraq, the United Arab Emirates opened International Humanitarian City (IHC). It has since become the largest humanitarian aid centre in the world. Nearly 100 organizations collaborate under IHC, including United Nations agencies. Moreover, in 2004, the UAE launched the Dubai International Humanitarian Aid \& Development Conference \& Exhibition (DIHAD), which has been held annually since then. It is an event that attracts global attention to the UAE. Dubai has become an international humanitarian hub of the world. This is not only the case in the context of logistics but also in meetings of leaders, companies, governmental and non-governmental organizations, and international organizations. Dubai attracts new projects and initiatives to help wherever help is needed around the world, especially in places affected by disasters, natural disasters, and crises where people suffer. The Khalifa Bin Zayed Al Nahyan Foundation was established in Abu Dhabi in July 2007. Its task is to support innovative initiatives for health and education and to provide healthy water around the world. The activities of the foundation are global, supporting projects in 87 countries. In addition, it actively supports multilateral initiatives within the United Nations. In September 2007, Dubai Cares was founded. Its mission is to help developing countries ensure access to education. The organization has so far provided support in 60 countries. The increasing international involvement of the UAE in foreign aid forced the creation of an organizational framework for humanitarian diplomacy. Therefore, in 2008, the Foreign Aid Coordination Office was established (Gökalp 2020). From the following year, the United Arab Emirates, as the first GCC country, has started regularly publishing foreign aid reports.

In 2011, when the so-called Arab Spring started, International Humanitarian City moved to a strategic location in Dubai from a logistics point of view. Moreover, it was expanded and increased by $300 \%$. In addition, a crisis in Syria began during that same year. As a result, the United Arab Emirates provided USD 700 million to support refugees from Syria. In addition, the United Arab Emirates delivered humanitarian aid to Syrian residents who had to be displaced within the country and provided financial and material support to Jordan, who received the most refugees from Syria. In addition, over 100,000 citizens with Syrian passports arrived in the UAE. Thus, refugee in the United Arab Emirates grew to over 240,000, making it one of the largest groups of Syrian refugees. In December 2012, the UAE Minister of Foreign Affairs and International Cooperation opened the International Centre of Excellence for Countering Violent Extremism, known as 'Hedayah', based in Abu Dhabi.

To make foreign aid more effective and significant for the UAE, the Ministry of International Cooperation and Development (MICAD) was established in 2013. The Foreign Aid Coordination Office joined the structures of the new ministry. Sheikha Lubna Al Qasimi became the Minister of International Cooperation and Development. Until that time, she was the minister of foreign trade. Sheikha was also the first woman to hold a ministerial position in the UAE government. According to Forbes, she was recognized as one of the most influential women in the world. In 2013 the United Arab Emirates became one of 
the largest donors in the world. At that time, the UAE exceeded $0.7 \%$ of gross national income allocated to aid, which exceeded the UN target. It also should be noted that the change in the UAE foreign aid dynamics is related to the country's adaptation to its international environment and new global conditions. Therefore, the so-called Arab Spring and its subsequent consequences had an impact on the United Arab Emirates' humanitarian diplomacy. In September 2013, because of activity within the Group of Friends of the Syrian People and its Working Group on Economic Recovery and Development, the United Arab Emirates, along with the USA and Germany, established the Syrian Recovery Trust Fund (SRTF). The purpose of this fund is to provide grants for humanitarian aid projects in Syria. Another example is Egypt, which experienced political changes in 2013 that served the interests of the UAE. This year, the country significantly increased its foreign aid by $375 \%$, of which Egypt received over 78\%. The domestic political situation in Egypt in 2019 remained tense. However, the country's economy recorded a much better state than before 2014 (Butter 2020). When assessing the UAE's commitment to boosting relations with Egypt from 2014, including foreign aid provisions, its effects should be noted. Since the inauguration of President Sisi on 7 June 2014, Emirati-Egyptian relations have taken on a strategic character. Since then, more than 20 high-level visits have taken place. In addition, regular political consultations between foreign ministers have taken place every six months since February 2017. Egypt supports the United Arab Emirates' positions on many international issues, including Yemen, Libya, Syria, and Qatar. Moreover, with the normalization of UAE-Israel relations based on the Abraham Accords and involvement in the East Mediterranean Gas Forum, the importance of Egypt for the United Arab Emirates continues to increase (Frantzman 2020).

1 July 2014, the United Arab Emirates became a participant of the OECD Development Assistance Committee (DAC). Thus, UAE gained a greater opportunity to participate in discussions and programming development cooperation. The United Arab Emirates has actively participated in the Global Coalition to Defeat Daesh since its inception in September 2014. To support this initiative, the UAE, together with the United States, established the 'Sawab' Centre in Abu Dhabi in July of 2015. Its task is to fight against extremism (U.AE 2019). The United Arab Emirates also supports the Funding Facility for Stabilization (FFS) in Iraq. It was founded in 2015 and is managed by the United Nations Development Program (UNDP). Projects implemented by the fund meet SDGs 3, 4, 5, 6, $8,9,11$, and 16 (UNDP 2021). In 2015, the outbreak of the war in Yemen exacerbated the dramatic humanitarian situation in that country. The UAE transferred humanitarian aid to Yemen. In 2015, the United Arab Emirates recorded the highest ODA to Gross National Income ratio (GNI), 1.09\% (USD 4.39 billion). At the same time, the United Arab Emirates was among the world's top ten donors of development aid (ODA). On 4 October 2015, the United Arab Emirates launched the Mohammed Bin Rashid Al Maktoum Global Initiative. Humanitarian aid has become a significant element of this project. Its goal is to strengthen the UAE brand in the world and to increase the scope of soft power (Gibbins 2017). The new initiative coincided with the 2030 Agenda, i.e., the Sustainable Development Goals, which had been announced by the United Nations ten days earlier. Sustainable development has become the main indicator for the implementation of foreign aid by the United Arab Emirates. In this way, the UAE, through its commitment to the SDGs and adapting their foreign policy to new challenges, assumed the role of a global player, influencing the shaping of new international initiatives.

\subsubsection{Foreign Aid Strategy 2017-2021}

The growing foreign aid importance in the UAE's foreign policy evidence was the merger of the Ministry of International Cooperation and Development (MICAD) with the Ministry of Foreign Affairs in 2016. The new ministry took over the name of the Ministry of Foreign Affairs and International Cooperation. On the other hand, a member of the government, Minister of State Reem Al Hashimy, was responsible for international cooperation, including foreign aid. In December of the same year, the United Arab Emirates 
adopted the United Arab Emirates' foreign aid strategies. The document, titled 'Promoting Global Peace and Prosperity: UAE Policy for Foreign Aid, 2017-2021' is based on the United Arab Emirates' commitment to supporting the Sustainable Development Goals that the international community has committed to achieving by 2030 (Bader 2020). According to the UAE's foreign aid policy, humanitarian aid in line with the Sustainable Development Goals is one of its most significant parts. In 2017, the OECD ranked the United Arab Emirates as the largest official development aid donor in the world for the fifth time, providing 147 countries with USD 5.3 billion (The National 2018).

The United Arab Emirates' strategy relies on four pillars. The first is effective foreign aid. This is the result of the fundamental values on which the state was established. However, in terms of foreign policy, it is supposed to strengthen the UAE's image. This country is active in the international arena for peace, tolerance, and stability. Another pillar of the program is technical cooperation. This contributes to an increase in the effectiveness of the impact of foreign aid. In addition, by sharing knowledge and experience with beneficiaries, the United Arab Emirates has a broader ability to shape its programs and initiatives. The third pillar of the strategy is an activity in international organizations as part of multilateral diplomacy. In recent years, the United Arab Emirates has stimulated relations not only within the GCC but with the European Union as well. Significant diplomatic activities have resulted in the location of the headquarters of the International Renewable Energy Agency in the capital of the UAE. Finally, the fourth pillar of the foreign aid strategy is the organization of many important international events in the United Arab Emirates and reporting initiatives significant to the international community, including foreign aid. Currently, one of the most important events is World Exhibition Expo 2020, which will take place in Dubai from October 2021-March 2022. Therefore, this global mega-event is an enormous soft power tool, which can be defined as the ability to influence others through networks with the ability to persuade according to the goals of the United Arab Emirates (Nye 2004).

The UAE's Foreign Aid Policy 2017-2021 also defined goals in addition to its four pillars. One of them is to improve lives and to reduce poverty around the world. Another goal is to work in the region for stability, peace, and prosperity. Subsequently, the United Arab Emirates intends to strengthen alliances with other countries. By building numerous coalitions, the United Arab Emirates wants to expand trade and investment pacts for the sustainable development of developing countries. In addition, three priority areas of assistance have been identified, namely infrastructure, government effectiveness, and women's empowerment. These areas offer many opportunities for the UAE to present its achievements and to strengthen the country's brand. At the same time, it will be linked to the activity of the United Arab Emirates to meet the SDGs. However, most of the United Arab Emirates' aid programs are targeted to the Middle East and the Arab world (MOFAIC 2017a, p. 14). The Foreign Aid Strategy 2017-2021 is proof of the creative adaptation of the United Arab Emirates' foreign policy.

\subsection{UAE Soft Power Strategy}

Soft power means the ability to influence others and to achieve one's goals through subtle actions and unforced partners decisions, serving the interests of the acting player. However, economic resources and donations can be more than an element of soft power. Combined with the pressure of compulsion, they also become part of hard power. (Nye 2004). However, this research focuses on one of the traditional soft power elements, which is humanitarian, development, and foreign aid. The economic element present in it is shown as attractive, not coercive. Nevertheless, the effectiveness of soft power depends on the global image of the country and its brand (Günek 2018). To this end, the United Arab Emirates adopted the Soft Power Strategy. Its purpose is to identify actions to develop the state's reputation. Humanitarian aid is one of the most crucial elements of enhancing the country's image and, consequently, strengthening the UAE's soft power (Gibbins 2017). This leads to the UAE strengthening its international position (Mills 2017). Kamrava (2013, 
p. 12) underlines that small Gulf states, emphasize soft power and implement foreign policy that is based on strategies of diplomatic hedging and dynamic branding. Small states, especially the United Arab Emirates, proactively reach regional influence due to creative soft power instruments (Almezaini and Rickli 2017). In the 21st century, the UAE intensified its foreign policy by developing soft power tools. As Ulrichsen (2017, p. 167) notes, this resulted in gaining prestige around the world. Thanks to foreign aid, the UAE has strengthened its image and has developed diplomatic relations with aid recipients. This can be an effective tool in achieving the interests of the United Arab Emirates (Almezaini 2011, p. 114).

In April 2017, the United Arab Emirates established the Soft Power Council. The Minister of Cabinet Affairs and the Future became its chairman. Its most important goal is to implement a soft power strategy. This is a significant part of the country's brand (Günek 2018). To this end, the Council primarily coordinates initiatives through both the public and private sectors. In September of the same year, the United Arab Emirates announced Soft Power Strategy (Woodward 2018), aiming to strengthen the UAE's global reputation. One of the main tasks has become to ensure cooperation between many sectors for humanitarian aid. The strategy is based on six pillars of diplomatic activity. The document mentions humanitarian diplomacy, consolidating initiatives, and increasing investments in humanitarian aid. It is supposed to strengthen the United Arab Emirates position as a soft power (Aldroubi 2018). A Member of the Soft Power Council, the Public Diplomacy Office Director-General in the Ministry of Cabinet Affairs and Future, Saeed Mohammad Al Eter emphasized that the soft power strategy presents the UAE's vision and comprehensive framework for increasing its position in the world (Gulf News 2017).

According to Al Zaabi and Awamleh (2019, p. 67), foreign aid is one of the main pillars of the UAEs' soft power. Another is foreign policy and a sustainable environment. The United Arab Emirates has dynamically increased its role and importance as a global humanitarian aid hub. This is due to the consistent implementation of plans, assumptions, and strategies. The diplomatic activity of the UAE also contributed to this, making it possible to establish partnerships in many international projects at the bilateral and multilateral level, including within international organizations. The success of United Arab Emirates diplomacy as a soft power was the award of Abu Dhabi as headquarters for the International Renewable Energy Agency, a new international organization under which global leaders are looking for global new solutions for renewable energy sources (Hertog 2017, p. 14). It has also become an instrument of providing foreign aid to LDC states. It should also be noted that the role and importance of the United Arab Emirates' soft power infrastructure allows for the effective implementation of foreign aid, including humanitarian aid. One of its elements is the constantly developing modern network of roads and highways. However, in the international dimension, the seaports and airports of the UAE play a key role. There are 11 seaports in this country. One of the world's largest container terminals, Port Jebel Ali, is located near International Humanitarian City. Additionally, the new Khalifa Port is situated between Abu Dhabi and Dubai, sixty kilometres from IHC. It is another added value for foreign aid and soft power strategy implementation. Moreover, the UAE has 12 airports that are ready to receive the biggest aircrafts. One of the world's largest airports is Dubai International Airport. Abu Dhabi International will soon join this group. International Humanitarian City is in the middle of both airports, i.e., $70 \mathrm{~km}$ from Dubai and $78 \mathrm{~km}$ from Abu Dhabi. In addition, Al Maktoum Airport is near the IHC. It is to be expanded in the future and will become the largest airport in the world. UAE airlines, especially Emirates Airlines, one of the world's largest airlines, also play a significant role in providing foreign aid. The World Exhibition Expo2020 will be held from October 2021-March 2022 and is located near the International Humanitarian City. For soft power, the Expo is one of the crucial mega-global events, offering enormous opportunities for humanitarian diplomacy and for strengthening the country's brand (Saberi et al. 2018). Expo 2020 Dubai is the first World Expo to be held in Middle Eastern, African, South Asian, and Arab countries. Expo 2020 Dubai has a significant voice in the context of foreign aid, 
including humanitarian aid. Due to the UAE's financial and organizational support, every country has its national pavilion. This is the case for the first time in history. It also fits in the implementation of the SDGs assumptions and increases the United Arab Emirates' instruments of influence. Moreover, it will improve the effectiveness of the Soft Power Strategy (Krzymowski 2020c, p. 3). After Expo 2020, a new Dubai business centre will be established in this area. This will create new potential for the IHC development and for the effective implementation of the UAE Soft Power Strategy. In this regard, it is also worth emphasizing the potential and role of Sovereign Wealth Funds. According to the rankings by total assets, the Abu Dhabi Investment Authority ranks third globally. While the Investment Corporation of Dubai ranks twelfth in the world as the Sovereign Wealth Funds (SWFI 2019). According to the 2021 ranking, the United Arab Emirates ranks first in the Middle East and North Africa region and 17th in the world in terms of soft power. It is one place up compared to 2020 (Brand Finance 2021).

When assessing the use of soft power by the UAE and the implications, it should be emphasized that its instruments are valuable. It has contributed to increasing this state's role in the international arena and to developing the country's brand. However, the United Arab Emirates' foreign aid was not always effective in reaching all those in need. The main reason for this was on the side of the recipients of aid. Nevertheless, in terms of its significance for soft power effectiveness, it was effective. It has provided an increase in the possibility of influencing the international environment.

\subsection{Sustainable Development Goals}

As Almatrooshi (2019) points out, the goal of the United Arab Emirates foreign aid policy is to support the fulfilment of ten Sustainable Development Goals, i.e., the 1, 3, $4,5,7,8,9,13,16$, and 17 . Thus, through foreign aid, the UAE intends to contribute to ending poverty in all of its forms everywhere; ensure inclusive and quality education and promote lifelong learning; achieve gender equality and empower all women and girls; promote inclusive and sustainable economic growth, employment, and decent work for all; build resilient infrastructure, promote sustainable industrialization, and foster innovation; reduce inequality within and among countries; promote peaceful and inclusive societies and build effective, accountable, and inclusive institutions at all levels; and revitalize the global partnership for sustainable development (Krzymowski 2020a).

In terms of the SDGs, the United Arab Emirates is active internationally. In the context of foreign aid and its consequences for the implementation of UN Agenda 2030, it cooperates, among others, with the Agency for Palestine Refugees in the Near East (UNRWA). It provides financial support to the International Federation of the Red Cross and Red Crescent Societies. The aid mainly covers natural disasters. In addition, it supports the activities United Nations Office for the Coordination of Humanitarian Affairs (OCHA), the United Nations High Commissioner for Refugees (UNHCR), the United Nations Children's Emergency Fund (UNICEF), the World Food Program (WFP), and the World Health Organization (WHO). However, from the foreign aid analysis point of view, an interesting example of the SDGs and soft power is the deepening of relations between the UAE and the European Union that has been taking place for several years. Scandinavian member states of the European Union have been the unquestioned leaders of rankings for years, both in terms of soft power and the implementation of Sustainable Development Goals terms.

\subsubsection{Institutional Background}

The United Arab Emirates has been an active player in achieving the SDGs from the outset. Representatives of this country participated in the development of the 2030 Agenda. The UAE Minister of Foreign Affairs and International Cooperation was the UN Secretary General's High-Level Panel on Global Sustainable Development member. In addition, the United Arab Emirates took an active part in the elaboration of the Sustainable Development Goals as part of the United Nations Open Working Group. Therefore, the UAE implements 
all its assumptions, both in terms of strategy and in the activities of the authorities. Foreign aid, which is one of the pillars of foreign policy, is a key in ensuring effectiveness in meeting 10 out of 17 SDGs, i.e., 1, 3, 4, 5, 7, 8, 9, 13, 16, and 17 (MOFAIC 2017a, p. 12).

To accelerate and coordinate efforts for the SDGs, the UAE established the National Committee for Sustainable Development Goals in 2017. It was composed of representatives from government institutions. The UAE Minister of State for International Cooperation, Reem Al Hashimy, has been nominated as its chairwoman. In addition, a Private Sector Council for Sustainable Development has been founded. It aims to improve the publicprivate partnership. Moreover, the government has established the United Arab Emirates Sustainable Development Goals Advisory Council, which is composed of a younger generation. In January 2018, the UAE Ministry of Foreign Affairs and International Cooperation signed a cooperation agreement with the European External Action Service. Its goal is to develop strategic cooperation, including in the areas related to the SDGs (EEAS 2018). In February 2018, during the annual World Government Summit in Dubai, the Global Council for Sustainable Development Goals was established. It aims to establish a multi-level and multi-dimensional network of cooperation between governments, international organizations, non-governmental organizations, the world of science, and business. In addition, the UAE Minister of State for International Cooperation was elected as its chairwoman (Lootah 2019). Moreover, during the summit, the United Arab Emirates launched the Humanitarian Logistics Data Bank. It is a project that enables real-time information exchange on crises and the effective distribution of humanitarian aid. Thanks to this platform, the international community can respond efficiently to the needs of the world. It contains information about through which seaports and airports assistance such as food and medicine, can be delivered quickly and efficiently.

The United Arab Emirates represents the country that has achieved the most progress in achieving the Sustainable Development Goals in the Middle East and North Africa region (Göll et al. 2019). Moreover, reports from the UAE Ministry of Foreign Affairs and International Cooperation on foreign aid indicate that more than half of the allocated funds focus on achieving peace and justice, economic growth, and poverty eradication initiatives, i.e., 17 SDGs. The Minister of State for International Cooperation, Reem Al Hashimy, emphasizes that the UAE's foreign aid strategy is an instrument for the implementation of the UN 2030 Agenda.

\subsubsection{Case Study: UAE-EU Cooperation}

The purpose of this case study is to test the UAE's ability to build alliances with actors that are internationally active in providing humanitarian aid and Sustainable Development Goals. In addition, the ability to form partnerships is a crucial issue in the effectiveness of soft power. The diplomacy of the United Arab Emirates has undertaken numerous activities in the international arena. Including, it has established a closer relationship for the achievement of the SDGs and foreign aid with the European Union. It is the most committed regional international organization in these areas in the world. Moreover, from the beginning, some of its members have been leaders in implementing the UN Agenda 2030 assumptions. As a result, the UAE Federal National Council (FNC) speaker met with the High Representative of the Union for Foreign Affairs and Security Policy, who was the Vice President of the European Commission at the same time, in Brussels in April 2016. During the meeting, she highlighted the role, importance, and achievements of the UAE in listing eight Sustainable Development Goals. In particular, she appreciated the commitment to tolerance, the fight against radicalism, and the role of women in social life. They focused on the issues of peace in the Middle East and the situation in Yemen, Syria, and Iran (EEAS 2016). Moreover, both sides started regular expert meetings to develop a joint EU-UAE cooperation plan to meet the SDGs (Mouriadou 2016). In January 2017, the European Commission Vice President, who is responsible for employment, growth, investment, and competitiveness, came to the UAE to strengthen cooperation with the United Arab Emirates, including in Sustainable Development Goals (Stur 2017). In January 
2019, the President of the National Federal Council of the United Arab Emirates paid another visit to Brussels. She met with the High Representative of the European Union for Foreign Affairs and Security Policy and the Vice President of the European Commission, who emphasized that the UAE is a strategic partner of the European Union in foreign aid. In addition, she has expressed that the United Arab Emirates plays a vital role and importance in the implementation of SDGs 1, 4, 5, 8, 9, 10, 16, and 17. In this context, both sides discussed humanitarian aid in Yemen. Moreover, the UAE Federal National Council met with the President of European Parliament. The interlocutors committed to deepening cooperation in the Middle East and North Africa to increase security, especially in the fight against terrorism and illegal immigration, using humanitarian assistance. During this visit, the FNC, in cooperation with the EU-UAE Parliamentary Friendship Group, organized a seminar called 'From Humanitarian Aid for Stability: The United Arab Emirates and European Union together. Its participants, including the EU Commissioner for Humanitarian Aid and Crisis Management, Christos Stylianides, emphasized the importance of humanitarian aid for the United Nations 2030 Agenda. The UAE's activity in this area was defined as exemplary for the international community. Therefore, EU representatives called for greater cooperation in humanitarian aid and the Sustainable Development Goals. The European People's Party Secretary General and European Parliament Member, Antonio López-Istúriz White, stressed that both sides should join efforts in foreign aid to be more effective in the fight against terrorism. Meanwhile, the Red Cross Office in the EU director, Denis Haveaux, emphasized that his organization was ready to implement many projects with the Red Crescent, especially for the benefit of the victims of various crises (Sheena 2019). During the visit, an exhibition was also presented to the European Parliament on the humanitarian aid that is undertaken by the United Arab Emirates around the world. The Deputy Secretary General for International Aid UAE Red Crescent Authority stressed that the United Arab Emirates' humanitarian and development aid is directed primarily to refugees and people in need from Syria, Yemen, Somalia, Palestine, Afghanistan, and Iraq. By implementing its commitment in this area, the UAE has been ranked first in the world for the fifth time in terms of the level of humanitarian and development aid concerning national GDP (Esraa and Rasha 2019). During July of that same year, political dialogue between the UAE and the European Union was launched in Brussels. The meeting was chaired by the Secretary General of the European External Action Service and the UAE Minister of State for Foreign Affairs. Both sides expressed their readiness to cooperate in humanitarian aid and the Sustainable Development Goals as priorities. In this sense, the partners discussed the challenges in Syria, Yemen and Sudan, Libya, Iraq, Afghanistan, and in the Horn of Africa and the Sahel. In addition, the parties emphasized that Expo 2020 Dubai is an opportunity to present joint projects in these areas to the world. Moreover, thematic Working Groups were established to develop joint activities (Alfaham 2019). Further deepening relations, in January 2020, the UAE Minister of Foreign Affairs and International Cooperation met the High Representative of the European Union for Foreign Affairs and Security Policy of the EU and the Vice President of the Commission for the European Union in Brussels.

The conducted case study shows the increased dynamics of the UAE's activity in the international arena in gaining allies as a result of the Soft Power Strategy being implemented. To this end, foreign aid and efforts to meet the Sustainable Development Goals are crucial elements for the United Arab Emirates. In this sense, the European Union is a desirable partner for the UAE. Moreover, both sides have developed multilateral diplomacy with a focus on foreign aid and the SDGs. Therefore, cooperation between the United Arab Emirates and EU has prospects for a deeper alliance.

\section{Discussion: Findings}

\subsection{Foreign Aid}

The research indicates that in the period of 2013-2019, the United Arab Emirates was the world leader in Official Development Assistance (ODA), measured by Gross 
National Income (GNI). The United Nations General Assembly (UNGA) has adopted the recommendation that states donate 0.7 GNIs to Official Development Assistance. The UAE was the only country in the world that took first place four times during this period. Moreover, it is the only country outside of Europe to rank in the top ten every year. At the same time, the study shows that in the period 2013-2019, only 6-7 countries out of 193 met the 0.7 GNI requirement for Official Development Assistance (Figure 1).

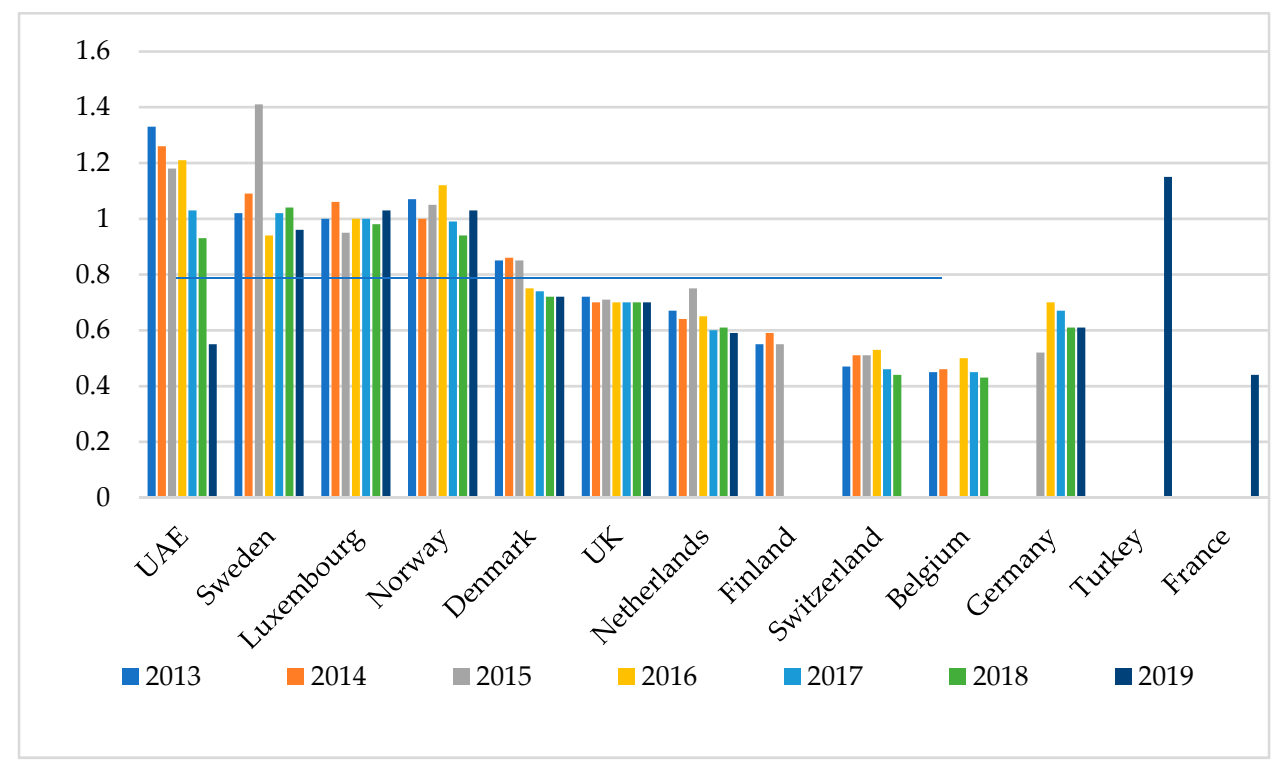

Figure 1. Top World Donors in relation to ODA/GNI in 2013-2019. Source: elaboration of the author-based on the UAE MOFAIC reports.

The study also shows the largest increase in the amount of money allocated in a given period was in 2015 (Figure 2), i.e., the time in which the war in Yemen broke out. The then dynamic situation in this country and the active role of the UAE shows the adaptation to the changes taking place. Therefore, one should agree with the theoretical assumption of Rosenau (1981), which emphasizes the role of the state in international relations as a result of adaptation.

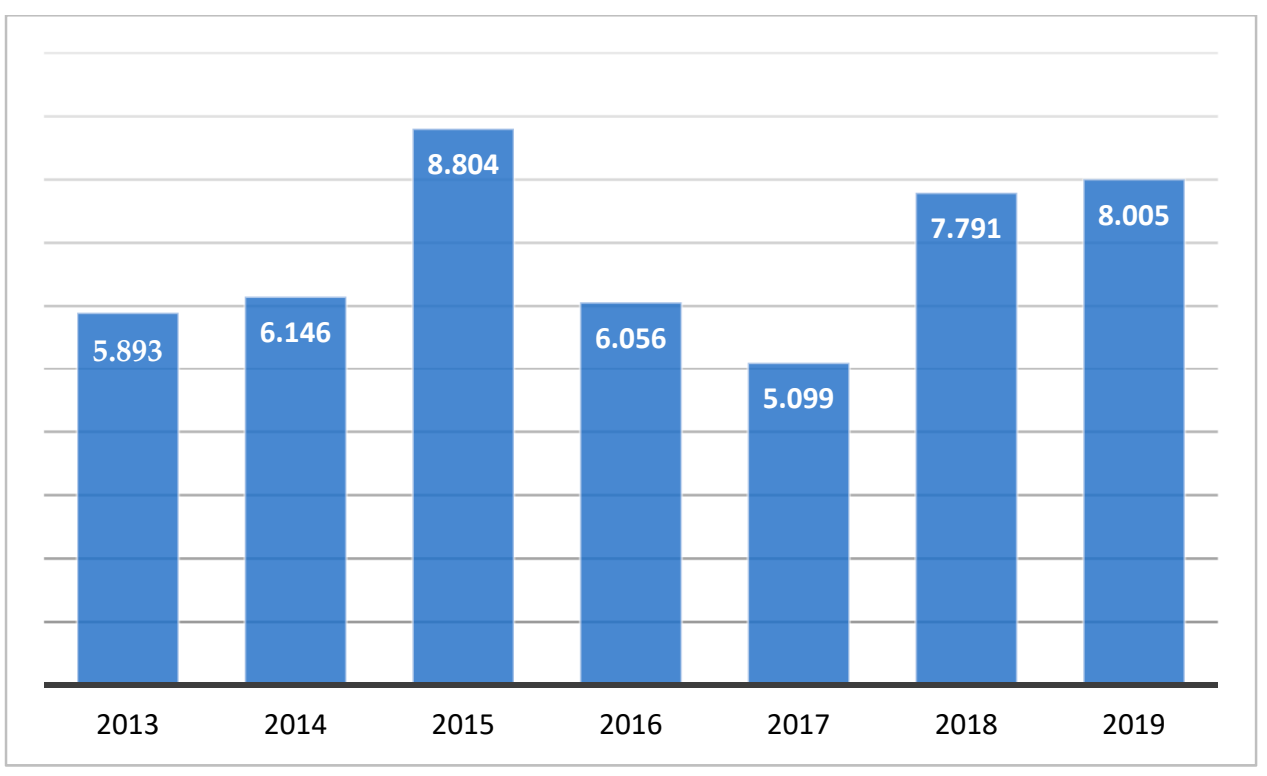

Figure 2. UAE Total Foreign Assistance in 2013-2019 (in USD millions). Source: Elaboration of the author-based on the UAE MOFAIC reports. 
The study shows the dynamics of change and foreign aid in the context of several continents and regions. The highest increases in expenditure for Africa were in 2013 and 2015. In contrast, from 2015 to 2018, there was a deep commitment to the UAE's foreign aid to Asia (Figure 3). In addition, the research results show that development projects throughout the period under study had a clear priority.

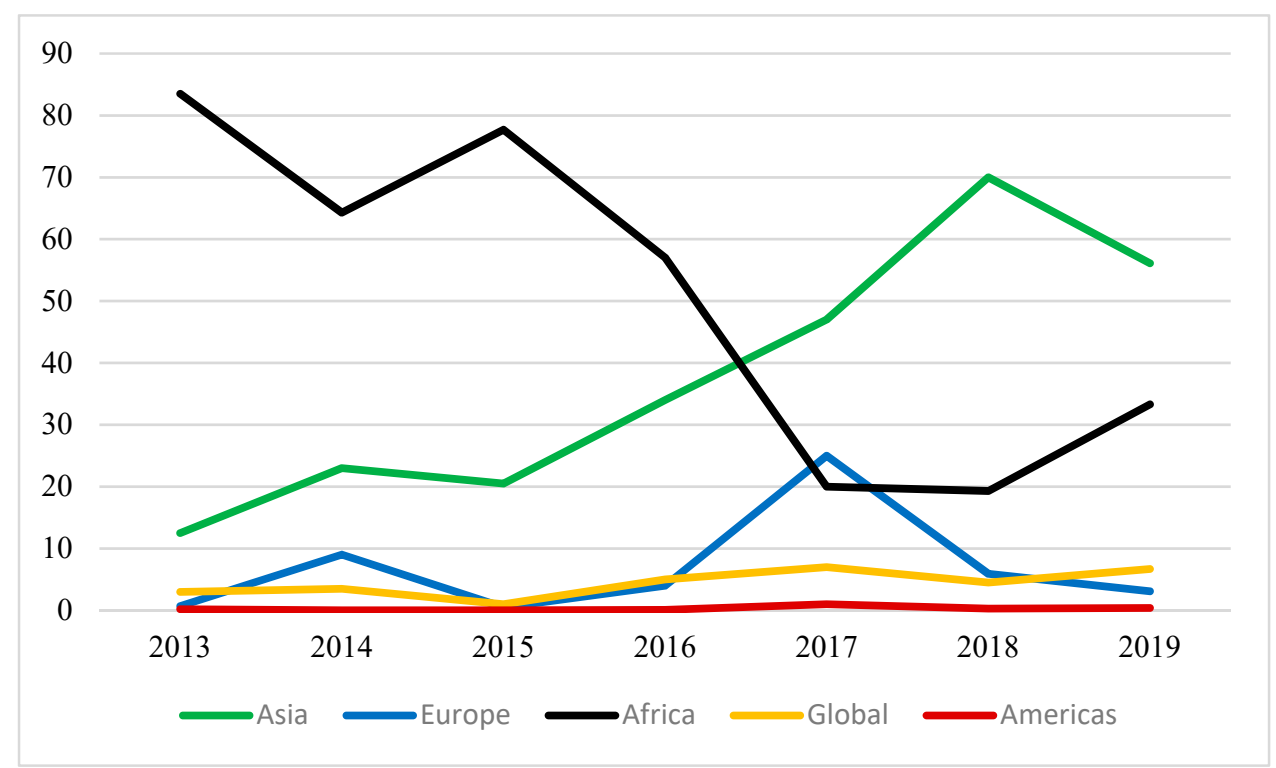

Figure 3. UAE Foreign Assistance Distributions in \% by regions (2013-2019). Source: Elaboration of the author-based on the UAE MOFAIC reports.

A detailed analysis of the beneficiary countries shows that the dynamic increase in expenditure for Africa mainly from the support of Egypt, which underwent revolutions in 2013. At that time, the country received as much as $79 \%$ of all foreign aid provided, which constituted USD 4.63 billion. The following year, despite the decline, Egypt was still the largest recipient of UAE aid, receiving USD 3.196 billion, more than half of the United Arab Emirates' total foreign aid budget. However, in 2015, there was another dynamic increase to the level of $72 \%$ of all foreign aid that went only to Egypt, which amounted to USD 6.339 billion. In 2016, there was a drastic change. Then, Yemen received 57\% of the UAE's foreign aid, amounting to USD 3.452 billion. This is the result of the war that started in this country in 2015. From then on, Yemen became a priority. In 2017, the country received 55\% of the aid from the United Arab Emirates, which amounted to USD 2.804 billion. In 2018, Yemen received $75 \%$, USD 5.844 billion, the highest sum ever. In 2019, this country received $64.5 \%$ of UAE's foreign aid, USD 5.124 billion (Figure 4). The UAE's commitment to Egypt is also a great example of role and adaptation theory. In the face of changes taking place in Egypt, using foreign aid, the United Arab Emirates showed a creative adaptation. In this case, one must agree with the theoretical assumption of Evans and Bruce (1991, p. 325) that this type of creativity provides tools for influencing other actors of international relations.

For many countries globally, foreign aid is a significant element of the state's foreign policy and the pursuit of its national interests. In the case of the United Arab Emirates, as emphasized by Cochrane (2021) and the Ministry of Foreign Affairs and International Cooperation reports, the same phenomenon occurs. The UAE's foreign aid data show that it was mainly implemented on a 'point-by-point basis'. On the one hand, aid was distribute based on where conflicts and wars arose. On the other hand, foreign aid was also a response to the changing international environment. It was used to adapt the implementation of geopolitical and economic goals. 


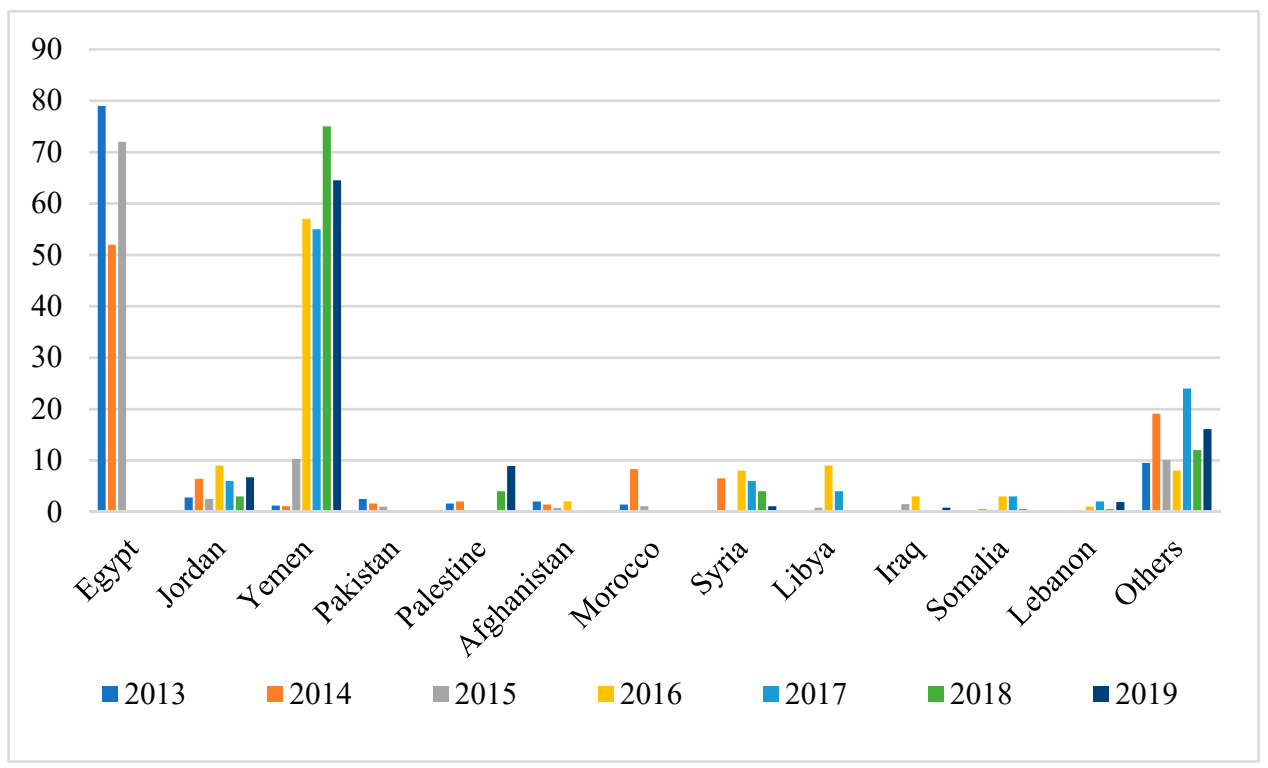

Figure 4. UAE Foreign Assistance Distributions in \% by countries (2013-2019). Source: elaboration of the author-based on the UAE MOFAIC reports.

\subsection{Sustainable Development Goals}

Analysing the United Arab Emirates foreign aid involvement in the SDGs context, ten were of particular important in the 2016-2019 period (MOFAIC 2020, p. 36). These were 1, 2, 3, 4, 7, 8, 9, 11, 16, and 17 (Figure 5).

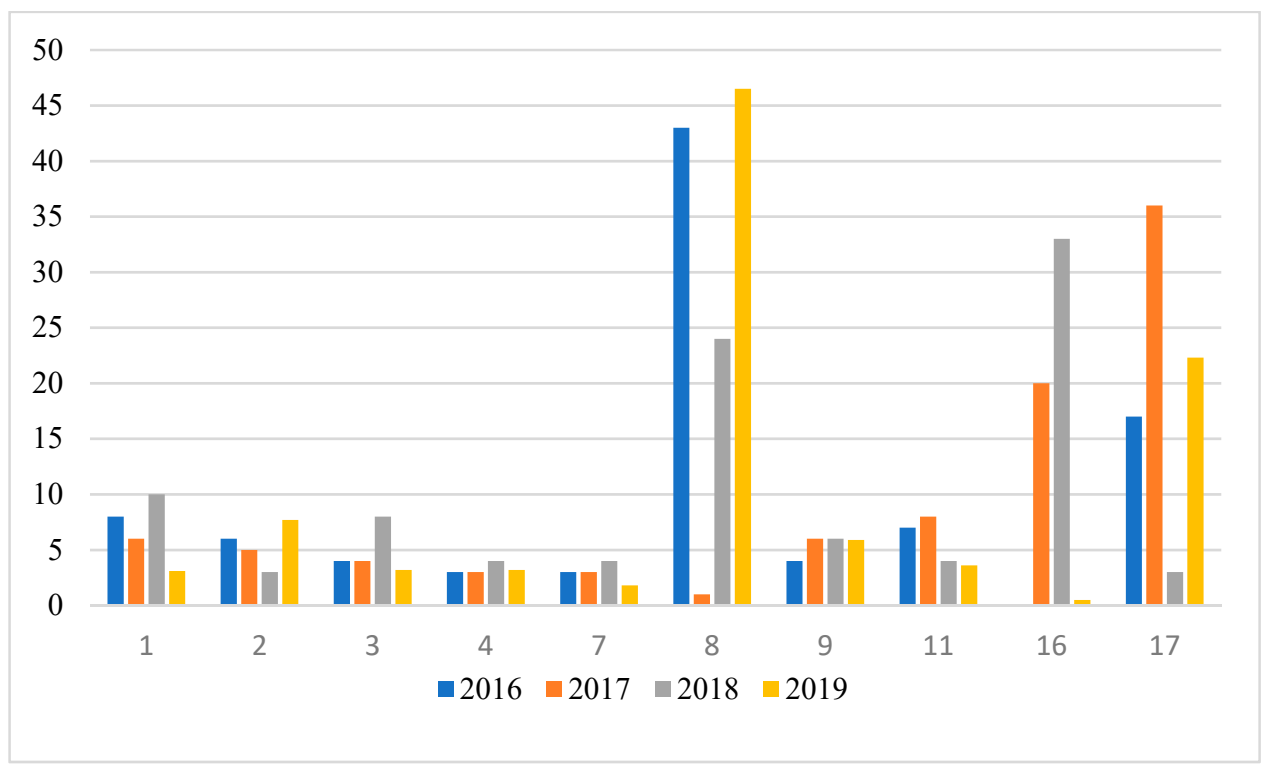

Figure 5. UAE Assistance to 17 SDGs in \% (2016-2019). Source: elaboration of the author-based on the United Arab Emirates Foreign Aid Report 2019.

In 2016, the first year in which the Sustainable Development Goals were implemented, the United Arab Emirates was one of the countries that was most committed to supporting LDCs. At that time, the largest funds were allocated to foreign aid related to SDGs 1, 8, and 17 . Nearly $70 \%$, i.e., USD 4.14 billion, was transferred with it, of which approximately $30 \%$ supported the world's least developed countries. In implementing overseas aid in the context of SDG 8, Decent Work and Economic Growth, the Middle East and North Africa (MENA) region was almost exclusively granted support to support government budgets, promoting micro and small enterprises. On the other hand, while implementing foreign aid 
related to SDG 17, Partnerships for the Goals, the UAE supported international programs and disabled people in Yemen, Syria, Iraq, and Palestine (MOFAIC 2017b).

In 2017, the United Arab Emirates continued its overseas support under SDG 17. In addition, that year, the country launched the UAE Technical Assistance Program (UAETAP). Its purpose is to share knowledge and experience with developing countries to support their potential. On the other hand, goals 1 and 8, as priorities from the previous year, were replaced with 11 and 16 Peace, Justice and Strong Institutions. For this purpose, the UAE allocated USD 1.04 billion almost exclusively in the form of subsidies. For SDG 11, Sustainable Cities and Communities, the United Arab Emirates transferred USD 414.6 million. A significant portion of this money was for Egypt, Morocco, Afghanistan, Mali, and Sudan (MOFAIC 2018).

In 2018, the provision of foreign aid under objective 16 was continued. However, as a priority, goal 17 and goal 11 were listed as goals 1 and 8 . It was a return to the 2016 priorities. More than half of the foreign aid was re-allocated to the Least Developed Countries (LDCs), including places experiencing war, such as Yemen and Syria. UAE aid under objective 1 was provided through grants only, supporting social care services and the health service (MOFAIC 2019). In 2019, the United Arab Emirates, despite an increase in spending on foreign aid compared to 2018 by USD 213.0 million, the GNI/ODO ratio fell below the UN requirement of 0.7 for the first time in the analysed period. In 2019, the priority was consistently from the beginning of goal 17 and, once again, goal 8 , under which aid was provided to Chad, Uganda, and Sudan, i.e., the three least developed countries. Egypt, Pakistan, Jordan, and Palestine were supported as low-middle-income countries. The support was given to projects related to tourism and women. Moreover, the UAE established an internet platform, 'Crowd Solving'. This platform supports innovative services aimed at building a cooperation network between start-ups, research centres, and businesses. Under Objective 17, decisions were made, inter alia, to write off Eritrea's debts. For the first time, goal 2, Zero Hunger, was prioritized. As part of it, the UAE supported projects, including in Yemen, Sudan, Egypt, Jordan, and Somalia, to improve the conditions for ensuring people's access to food. One example was the construction of a dam in Jordan. This dam is supposed to provide more water to this country, which should contribute to developing agriculture. Another example is the construction of a canal in Egypt called the Sheikh Zayed canal, which was implemented by the Abu Dhabi Foundation Development. It is intended to enable the creation of a new delta in the south, which will also increase the possibilities for agriculture.

UAE Foreign Aid contributes to the achievement of the SDGs. In 2016-2021, this country transferred USD 56.41 billion to foreign aid. The United Arab Emirates targeted specific SDGs (Sanz 2021). To achieve goal 1: No Poverty, and goal 2: Zero Hunger, the UAE extended a strategic partnership with the Food and Agriculture Organization of the United Nations (FAO). In October 2019, FAO launched the Hand-in-Hand Initiative, which has become one of the priorities for the United Arab Emirates. Its aim is the effective transformation of agriculture and the sustainable development of rural areas around the world. For example, while pursuing goal 4: Quality Education, the UAE has committed itself to the Global Partnership for Education (GPE) initiative, allocating approximately USD 100 million to 90 countries for the 2018-2020 period. In addition, the United Arab Emirates announced that it will provide the same amount in 2021-2025. To meet goal No. 5: Gender Equality, and 10: Reduced Inequality, as part of foreign aid, the UAE initiated the '100\% Women Policy' program in 2018. The United Arab Emirates had donated USD1.68 billion for this initiative by 2020. In addition, in pursuit of Goal 7: Affordable and Clean Energy, the UAE created special funds to support poor regions of the world to develop renewable energy. For this purpose, in 2010-2020, the United Arab Emirates transferred approximately USD 538 million as foreign aid (Godinho 2021).

De Lauri (2021) points out that the first pillar of the UAE Soft Power Strategy is humanitarian diplomacy. Therefore, it must be a priority in the broader dimension of foreign policy to pursue growing international political and economic ambitions. The 
symbiosis between donations and SDGs will ensure the effective implementation of the UAE Soft Power Strategy.

\subsection{Humanitarian Aid during COVID-19 Pandemic}

In the age of globalization, the world is experiencing transboundary crises. These are characterized by a simultaneous impact on many countries, regions, and economic areas. The COVID-19 pandemic is an apt example of this type of crisis that began with issues related to health and hit, among others, the economy, state, and society. Due to its global reach, it has raised the fundamental question of coordination between countries and humanitarian issues. The United Arab Emirates has demonstrated global commitment during this challenging time (Sahu 2021, p. 261). As Alexander et al. (2021) point out, in health diplomacy, the vaccine has become a foreign policy tool. Therefore, by adapting to the new situation, vaccine diplomacy is an opportunity for the UAE to increase its role and position in the world. Vaccine diplomacy is a combination of humanitarian, strategic goals, national, and global interests. The UAE used its position as a logistics hub and immediately established deep cooperation with vaccine manufacturers. In this way, the UAE has not only been able to achieve one of the world's highest vaccination levels, but it has also become an international centre for vaccine transport and distribution. Abu Dhabi and Dubai are crucial elements of the global vaccine supply chain. Dubai airport can handle 300 tons per day and store 10 million doses in distribution centres.

When the COVID-19 pandemic broke out, the United Arab Emirates was one of the first countries in the world to become globally involved. By mid-2021, the UAE had provided 2.154 tons of medical aid to 135 countries, making 196 flights. In addition, they built field hospitals in Guinea Conakry, Jordan, Lebanon, Mauritania, Sierra Leone, and Sudan. In Turkmenistan, the UAE organized an equipped mobile clinic. Moreover, Dubai International Humanitarian City provided aid to 117 countries (U.AE 2021). Alexander et al. (2021) point out that in November 2020, Abu Dhabi launched a public-private logistics partnership called Hope Consortium. The initiative involves collaboration between the Abu Dhabi Department of Health, Abu Dhabi Ports Company, Etihad Cargo, Rafed, and SkyCell. The consortium can distribute over six billion vaccines. By adapting to the new situation, The United Arab Emirates wants to increase its role in the international arena as a soft power. This is to be achieved through a new joint venture, formed by Sinopharm CNBG and Abu Dhabi's G42, which will produce 200 million doses of vaccines in the United Arab Emirates annually. In this way, the UAE will not only become a distributor but a global pharmaceutical producer.

The COVID-19 pandemic has increased problems related to hunger and poverty. Therefore, the United Arab Emirates has initiated many activities. One of them is the ' 100 million Meals' program. Thanks to this program, food aid reached 30 countries in Africa, South America, Asia, and Europe. A total of 216 million meals have been donated as a part of this initiative. As such, the goal has been exceeded more than twice. This program has delivered the possibility of creating a special cooperation platform involving donors from 51 countries and various international, regional, and local organizations (Elserougy 2021).

During the COVID-19 pandemic, The United Arab Emirates proved its creative adaptation to the new global situation to increase its role and position in the international arena. Thus, these activities are in line with the adopted theoretical model of Conway and Feigert (1987, pp. 136-39). Moreover, the analysis of the United Arab Emirates' activities proves that through dynamic interaction, the UAE has entered into a wider spectrum of interactions. Through humanitarian aid, it implements the Soft Power Strategy, SDGs, and shapes international relations under the national interest. It confirms the theoretical assumption of Keohane (2012, p. 19). 


\section{Conclusions}

The most significant results achieved in the presented research show that the institutional and personal responsibility for foreign affairs, aid, and SDGs have been combined in the United Arab Emirates. This indicates the role and importance of foreign aid for the United Arab Emirates. UAE foreign aid has supported the ten Sustainable Development Goals. According to the obtained results, the UAE invested 84 percent of its foreign aid budget since 2016. Of the USD 22.89 billion spent supporting the ten SDGs, 67\% went to the least developed and low-middle income countries. In 2019, this ODA-DAC group accounted for $75 \%$ of total of USD 8 million that had been invested. However, the overall picture of the study shows that foreign aid was a significant element of the United Arab Emirates' adaptation to changes in international relations. On the other hand, its dynamics have created its role as one of the world's largest foreign aid donors. A detailed analysis of the country shows that this is largely 'targeted'. The choice of who receive the largest amounts of aid result from their enormous need. This demonstrates that foreign aid is an instrument of influence in terms of international relations. The main contribution of the presented article to the studies on international relations development is the enrichment of this research area by providing a new scientific analysis, which shows the UAE's adaptation to the novel situation in the external environment. The UAE has become the top global donor of foreign aid.

The research results consider pandemic time to some extent. The reason for this is the lack of comprehensive reports that have yet to be released. The economic effects of the COVID-19 pandemic have influenced the re-review of the United Arab Emirates' ability to implement its foreign aid strategy. However, due to its role and importance for the state's foreign policy and soft power strategy, the UAE will not only continue to implement this instrument. In addition, the situation with the pandemic was also an opportunity to strengthen the image of the country as it is involved in humanitarian aid. In the postcoronavirus period, the United Arab Emirates will try to be involved in creating new humanitarian management mechanisms at the global level. It, in turn, will create new opportunities to strengthen the United Arab Emirates' role and position in the world. This issue should become the subject of a new research study.

Funding: This research was funded by Zayed University, grant number R20069.

Institutional Review Board Statement: Not applicable.

Informed Consent Statement: Not applicable.

Data Availability Statement: Not applicable.

Conflicts of Interest: The author declares no conflict of interest.

\section{References}

Al Zaabi, Fatima, and Raed Awamleh. 2019. Determinants of Soft Power: The Case of United Arab Emirates. In Future Governments. Actions and Insights—Middle East North Africa. Edited by Melodena Stephens, Mona El-Sholkamy, Immanuel Azaad Moonesar and Raed Awamleh. Bingley: Emerald Publishing Limited.

Aldroubi, Mina. 2018. UAE to take the international lead on soft power. The National, December 27. Available online: https: / / www.thenational.ae/world/gcc/uae-to-take-international-lead-on-soft-power-1.806868(accessed on 7 June 2021).

Alexander, Kristian, Leonardo Mazzucco, and Maria Jacopo. 2021. Vaccine Diplomacy-The UAE Tries to Balance Hard Times with Soft Power. Insight 261. Available online: https:/ / mei.nus.edu.sg/publication/insight-261-vaccine-diplomacy-the-uae-tries-tobalance-hard-times-with-soft-power/ (accessed on 29 November 2021).

Alfaham, Tariq. 2019. UAE, EEAS hold first Senior Officials' Meeting to launch the Cooperation Arrangement. WAM, July 27. Available online: https:/ / www.wam.ae/en/details/1395302776990(accessed on 5 June 2021).

Almatrooshi, Bader. 2019. The UAE's Foreign Assistance Policy and Its Contributions to the Sustainable Development Goals. Open Journal of Political Science 9: 669-86. [CrossRef]

Almezaini, Khalid S. 2011. The UAE and Foreign Policy: Foreign Aid, Identities and Interests. Florence: Taylor \& Francis Group.

Almezaini, Khalid, and Jean-Marc Rickli, eds. 2017. The Small Gulf States: Foreign and Security Policies before and after the Arab Spring. New York: Routledge. 
Baba, Gürol, and Taylan Kaya. 2014. Testing the creativity of Kevin Rudd's middle power diplomacy: EU-Australia partnership framework versus the Asia-Pacific community. International Relations of the Asia-Pacific 14: 239-69. Available online: https: / / www.jstor.org/stable/26156016 (accessed on 17 June 2020). [CrossRef]

Bader, Al-Saif. 2020. The UAE: Aid Serves Many Purposes. In As Gulf Donors Shift Priorities, Arab States Search for Aid. Edited by Michele Dunne. Riad El Solh: Carnegie Endowment for International Peace, Available online: https://carnegie-mec.org/2020/0 6/09/uae-aid-serves-many-purposes-pub-82004 (accessed on 17 April 2021).

Bartlett, Will, James Ker-Lindsay, Kristian Alexander, and Tena Prelec. 2017. The UAE as an Emerging Actor in the Western Balkans: The Case of Strategic Investment in Serbia. Journal of Arabian Studies 7: 94-112. Available online: https://doi.org/10.1080/215347 64.2017.1322753 (accessed on 7 June 2020). [CrossRef]

Brand Finance. 2021. Global Soft Power Index 2021. Available online: https:/ / brandirectory.com/globalsoftpower/download/brandfinance-global-soft-power-index-2021.pdf (accessed on 7 May 2021).

Butter, David. 2020. Egypt and the Gulf. Allies and Rivals. Research Paper 20. Available online: https://www.chathamhouse.org/2020 /04/ egypt-and-gulf (accessed on 7 January 2021).

Cochrane, Logan. 2021. The United Arab Emirates as a global donor: What a decade of foreign aid data transparency reveals. Development Studies Research 8: 49-62. [CrossRef]

Conway, Margaret, and Frank Feigert. 1987. Political Analysis: An Introduction. Boston: Allyn and Bacon.

De Lauri, Antonio. 2021. La diplomazia umanitaria. CMI Brief 3: 3. Available online: https://www.cmi.no/publications/7746-ladiplomazia-umanitaria (accessed on 29 November 2021).

EEAS. 2016. Federica Mogherini, HR/VP meets with Dr. Amal Al Qubaisi, UAE Federal National Council Speaker in Brussels. Press Releases: 160818_2. Available online: https:/ / eeas.europa.eu/topics/security-defence-crisis-response/8363/federica-mogherinihrvp-meets-dr-amal-al-qubaisi-uae-federal-national-council-speaker-brussels_en (accessed on 15 June 2020).

EEAS. 2018. EU and UAE sign a Cooperation Arrangement. Press Releases: 180131_15. Available online: https://eeas.europa.eu/ headquarters/headquarters-homepage/39170/press-release-eu-and-uae-sign-cooperation-arrangement_et (accessed on 15 June 2020).

Elserougy, Magdy. 2021. MoFAIC-Bericht: Die Auslandshilfe der VAE Belief Sich von 2010 bis 2021 auf 206 Milliarden AED. Available online: https: / / www.wam.ae/de/details/1395302963143 (accessed on 29 November 2021).

Esraa, Ismail, and Abubaker Rasha. 2019. UAE a global model for promoting peace through humanitarian role in Yemen, says EU President. WAM, January 14. Available online: http://wam.ae/en/details/1395302732327(accessed on 17 June 2020).

Evans, Gareth, and Grant Bruce. 1991. Australia's Foreign Relations in the World of the 1990s. Carlton, Victoria: Melbourne University Press.

Forrey, Danielle. 2020. The UAE's History of Foreign Aid Assistance. Borgen Project. Available online: https://borgenproject.org/tag/ uae-humanitarian-committee/ (accessed on 17 January 2021).

Frantzman, Seth. 2020. UAE-Egypt relations grow with Sheikh Mohamed bin Zayed visit to Sisi. The Cairo-Abu Dhabi relationship has grown strong. Jerusalem Post, December 17. Available online: https://www.jpost.com/middle-east/uae-egypt-relations-growwith-sheikh-mohamed-bin-zayed-visit-to-sisi-652421(accessed on 7 May 2021).

Gibbins, Justin. 2017. Power play: The United Arab Emirates' new approach to geopolitics. Journal of Middle Eastern Politics and Policy. Available online: http://hksjmepp.com/united-arab-emirates-geopolitics/ (accessed on 7 August 2020).

Godinho, Varun. 2021. UAE's foreign aid from 2010 to 2021 totalled \$56.14bn. Gulf Business. Available online: https: //gulfbusiness.com/uaes-foreign-aid-from-2010-to-2021-totalled-56-14bn/\#: :text=The\%20value \%20of $\% 20 \mathrm{foreign} \% 20$ aid, and\%20International\%20Cooperation\%20(MoFAIC) (accessed on 29 November 2021).

Gökalp, Deniz. 2020. The UAE's Humanitarian Diplomacy: Claiming State Sovereignty, Regional Leverage and International Recognition. CMI Working Paper no 1. February. Available online: https:/ /www.cmi.no/publications/7169-the-uaes-humanitariandiplomacy-claiming-state-sovereignty (accessed on 14 May 2021).

Göll, Edgar, André Uhl, and Jakob Zwiers. 2019. Sustainable Development in the MENA Region. MENARA Future Notes. Available online: http:/ / menaraproject.eu/wp-content/uploads/2019/03/menara_fn_20.pdf (accessed on 14 August 2021).

Gulf News. 2017. UAE's Soft Power Strategy discussed. Gulf News, September 26. Available online: https://gulfnews.com/uae/ government/uaes-soft-power-strategy-discussed-1.2096694(accessed on 8 August 2020).

Günek, Abdulsamet. 2018. A New Type of Soft Power: Country Branding. International Journal of Cultural and Social Studies 4: 252-59. Available online: https:/ / dergipark.org.tr/download/article-file/525907 (accessed on 18 August 2020).

Hertog, Steffen. 2017. A Quest for Significance: Gulf Oil Monarchies' International 'Soft Power' Strategies and Their Local Urban Dimensions. LSE Kuwait Programme Paper Series 42; London: The London School of Economics and Political Science, LSE Kuwait Programme.

Kamrava, Mehran. 2013. Qatar: Small State, Big Politics. Ithaca and London: Cornell University Press.

Katzenstein, Peter. 1985. Small States in World Markets. Ithaca: Cornel University Press.

Keohane, Nannerl. 2012. Thinking about Leadership. Princeton: Princeton University Press.

Kodabux, Adeelah. 2019. The Future of IR Lies in Creativity Rather than 'New Thinking'. E-International Relations. Available online: https: / / www.e-ir.info/2019/11/11/the-future-of-ir-lies-in-creativity-rather-than-new-thinking/ (accessed on 17 August 2020).

Krzymowski, Adam. 2020a. Expo2020 Dubai on the journey to achieve the United Arab Emirates' Soft Superpower. University of Sharjah Journal for Humanities \& Social Sciences 17: 1-21. 
Krzymowski, Adam. 2020b. Sustainable Development Goals in Arab Region-United Arab Emirates' Case Study. Problemy EkorozwojuProblems of Sustainable Development 15: 211-20. [CrossRef]

Krzymowski, Adam. 2020c. The European Union and the United Arab Emirates as civilian and soft powers engaged in Sustainable Development Goals. Journal of International Studies 13: 41-58. [CrossRef] [PubMed]

Lootah, Abulla Nasser. 2019. Excellence in Implementation': The UAE Model in Reaching the Global Agenda 2030. In EDA Reflection. Abu Dhabi: Emirates Diplomatic Academy.

Mills, Robin. 2017. Global Governance of Carbon Capture and Storage: Role for the GCC? In EDA Insight. Abu Dhabi: Emirates Diplomatic Academy, vol. 8.

MOFAIC. 2017a. Promoting Global Peace and Prosperity. UAE Policy for Foreign Assistance 2017-2021. Abu Dhabi: United Arab Emirates Ministry of Foreign Affairs and International Cooperation.

MOFAIC. 2017b. United Arab Emirates Foreign Aid 2016. Abu Dhabi: Ministry of Foreign Affairs and International Cooperation.

MOFAIC. 2018. United Arab Emirates Foreign Aid 2017. Abu Dhabi: Ministry of Foreign Affairs and International Cooperation.

MOFAIC. 2019. United Arab Emirates Foreign Aid 2018. Abu Dhabi: Ministry of Foreign Affairs and International Cooperation.

MOFAIC. 2020. United Arab Emirates Foreign Aid 2019. Abu Dhabi: Ministry of Foreign Affairs and International Cooperation.

Mouriadou, Georgia. 2016. EU-GCC Clean Energy Technology Network. Working Groups Consultation Workshop. Available online: http:/ / www.eugcc-cleanergy.net/wg-workshop2016\%2CDubai (accessed on 15 August 2020).

Nye, Joseph. 2004. Soft Power: The Means to Success in World Politics. Foreign Affairs, May/June.

Rosenau, James. 1981. The Study of Political Adaptation. London: Pinter, New York: Nichols.

Saberi, Donya, Cody Morris Paris, and Belisa Marochi. 2018. Soft power and place branding in the United Arab Emirates: Examples of the tourism and film industries. International Journal of Diplomacy and Economy 4: 44-58. [CrossRef]

Sahu, Mrutuyanjaya. 2021. Public policy measures for COVID-19 crisis management: Lessons from the UAE. Fulbright Review of Economics and Policy 1: 246-65. Available online: https://www.emerald.com/insight/content/doi/10.1108/FREP-09-2021-0054 / full/html (accessed on 29 November 2021). [CrossRef]

Sanz, Alba. 2021. Les EAU ont accordé plus de 54 milliards de dollars d'aide étrangère. Available online: https://atalayar.com/fr/ content/les-eau-ont-accord\%C3\%A9-plus-de-54-milliards-de-dollars-daide-\%C3\%A9trang\%C3\%A8re (accessed on 29 November 2021)

Sheena, Amos. 2019. UAE ranked world's top aid donor in 2017: OECD. Dubai Gazette, January 11. Available online: https: / / dubaigazette.com/uae-ranked-worlds-top-aid-donor-in-2017-oecd/(accessed on 11 August 2020).

Stur, Beata. 2017. Jyrki Katainen: 'There is untapped trade potential between GCC and Europe. NewEurope, January 30. Available online: https:/ / www.neweurope.eu/article/jyrki-katainen-untapped-trade-potential-gcc-europe/(accessed on 7 August 2020).

SWFI. 2019. Top 81 Largest Sovereign Wealth Fund Rankings by Total Assets. SWIFI Institute. Available online: https://www. swfinstitute.org/fund-rankings/sovereign-wealth-fund (accessed on 17 August 2020).

The National. 2018. UAE is the world's top donor of development aid in 2017, report shows. The National, April 9. Available online: https: / / www.thenational.ae/uae/government/uae-is-world-s-top-donor-of-development-aid-in-2017-report-shows1.720143(accessed on 7 June 2020).

U.AE. 2019. Centres for Countering Extremism. Available online: https://u.ae/en/about-the-uae/culture/tolerance/centers-forcountering-extremism (accessed on 29 November 2021).

U.AE. 2021.كوفيد جائحة خلال الإمارات لدولة الإنسانية الجهود 19. Available online: https://u.ae/en/information-and-services/justice-safetyand-the-law / handling-the-covid-19-outbreak/humanitarian-efforts\#: :text=The\%20UAE\%20was\%20one \%20of, when \%20 COVID \%2D19\%20broke\%20out.\&text=As\%20of\%20July\%202021\%2C\%20the,135\%20countries \%20around \%20the \%20world (accessed on 29 November 2021).

Ulrichsen, Kristian Coates. 2017. The United Arab Emirates: Power, Politics and Policy-Making. New York: Routledge.

UNDP. 2021. Funding Facility for Stabilization. Available online: https://www.iq.undp.org/content/iraq/en/home/all-projects/ funding-facility-for-stabilization.html (accessed on 7 September 2021).

Walker, Stephen, ed. 1987. Role Theory and Foreign Policy Analysis. Durham: Duke University Press.

Woodward, Richard. 2018. The UAE-Soft Superpower in The Making? TRENDS Research E Advisory, May 30. Available online: http:/ / trendsinstitution.org/the-uae-soft-superpower-in-the-making/(accessed on 7 July 2020). 